\title{
Metode Biblioterapi Islam Untuk Pengembangan Karakter Tanggung Jawab Pada Mahasiswa
}

\author{
Vivik Shofiah \\ Fakultas Psikologi UIN Suska Riau \\ Jl. Soebrantas Km 15 No.155 Pekanbaru, 28293 \\ Alamat e-mail: vivik.shofiah@uin-suska .ac.id
}

\begin{abstract}
This resarch aimed to know the effect of the method of bibliotherapy in enhancing responsible character. The subjects of the research were 11 students of psychology faculty UIN Sultan Syarif Kasim Riau divided into two groups, six (6) students in experiment group, five (5) students in control group. The research used nonequivalent control group design. The data of this experimental research were obtained by using scale choice and analyzed with calculate ratio gain score between experimen group and control group. Based on the hypothesis test, it was concluded that ratio gain score experiment group higher control group. It mean Islamic bibliotherapy method have effect to responsible character for students.
\end{abstract}

Key Word: islamic bibliotherapy, character, responsible.

\section{Abstrak}

Penelitian ini bertujuan untuk mengetahui pengaruh metode biblioterapi Islam dalam meningkatkan karakter tanggung jawab pada mahasiswa. Subjek dalam penelitian ini berjumlah 11 mahasiswa fakultas psikologi UIN Sultan Syarif Kasim Riau yang terbagi menjadi enam (6) mahasiswa menjadi kelompok eksperimen dan lima (5) mahasiswa menjadi kelompok kontrol. Penelitian ini menggunakan desain nonequivalent control group design. Data penelitian diperoleh dengan menggunakan skala karakter tanggung jawab dan di analisis dengan menghitung rerata gain skor kelompok eksperimen dan kelompok kontrol. Berdasarkan uji hiptesis diperoleh hasil bahwa rerata gain skor pada kelompok eksperimen $(-7,14)$ lebih tinggi dibanding dengan kelompok kontrol $(-0,58)$. Artinya metode biblioterapi islam berpengaruh terhadap pengembangan karakter tanggung jawab pada mahasiswa.

Kata Kunci : biblioterapi islam, karakter, tanggung jawab. 


\section{WACANA}

\section{Pendahuluan}

Mahasiswa sebagai masyarakat intelektual dan sekaligus sebagaiwarga negara tentu saja memiliki tugas dan tanggung jawab yang tidak ringan. Sebab, idealnya mahasiswa dituntut bukan hanya untuk cerdas dalam belajar,tetapi lebih dari pada itu juga harus kritis terhadap kenyataan sosial yang ada. Kenyataan inilah yang menyebabkan adanya "agent of change". Mahasiswa memiliki tanggung jawab untuk "merubah". Tidak harus merubah dunia, setidaknya merubah dirinya sendiri. Karena mahasiswa memiliki tanggung jawab untuk dirinya sendiri.Tanggung jawab terhadap diri sendiri menentukan kesadaran setiap orang untuk memenuhi kewajibannya sendiri dalam mengembangkan kepribadian sebagai manusia pribadi. Dengan demikian bisa memecahkan masalah-masalah kemanusiaan mengenai dirinya sendiri.

Mahasiswa dinantikan menjadi sosok manusia "utuh" seperti yang ada pada tujuan pendidikan yaitu menjadikan manusia seutuhnya. Artinya mahasiswa dapat menjadi manusia dewasa yang matang tidak hanya fisik namun juga secara psikis. Dewasa secara psikis maksudnya menjadi manusia yang berkarakter. Furqon (2010) menjelaskan karakter adalah kualitas atau kekuatan mental atau moral, akhlak atau budi pekerti individu yang merupakan kepribadian khusus yang menjadi pendorong dan penggerak, serta yang membedakan dengan individu yang lain. Karakter diperlukan mahasiswa dalam menentukan keberhasilan hidupnya karena karakter adalah kepribadian khusus yang menjadi penggerak mahasiswa dalam membangun bangsa yang bermartabat.

Karakter dibentuk melalui proses yang berkesinambungan, bukan bawaan sejak lahir. Hal ini dididukung oleh Helen G. Douglas (dalam Muchlas, 2012) bahwa karakter tidak diwariskan, tetapi sesuatu yang dibangun secara berkesinambungan hari demi hari melalui pikiran, perbuatan dan tindakan. Pendidikan karakter bertujuan untuk dapat membentuk watak/kepribadian anak bangsa sesuai yang tercantum pada UU Nomor 14 Tahun 2005 tentang sistem pendidikan nasional (sisdiknas) pasal 3 yaitu beriman dan bertakwa kepada Tuhan YME, berakhlak mulia, cakap, kratif, mandiri dan menjadi warga negara yang demokratis serta tanggung jawab.

Idealnya mahasiswa hendaknya berkarakter seperti yang diamanatkan dalam UU Nomor 14 Tahun 2005 termasuk salah satunya karakter tanggung jawab. Karakter tanggung jawab penting dikembangkan karena mahasiswa berada pada tahap transisi yang akan terjun langsung ke masyarakat di mana pada masa ini mahasiswa juga seharusnya sudah mampu bertanggung jawab atas keputusan atau pilihan yang akan diambil. Selain itu dilihat dari tugas perkembangan yang harus diselesaikan, menurut Hurlock (2000) mahasiswa berada dalam tahap perkembangan peralihan dari remaja akhir ke dewasa dini yaitu pada usia 18-21 


\section{WACANA}

tahun. Pada masa ini remaja dituntut untuk mencapai tugas perkembangan moral yaitu mempelajari apa yang diharapkan kelompok, kemudian membentuk perilakunya agar sesuai dengan harapan sosial yang universal tanpa pengawasan, dorongan, dan ancaman hukuman seperti pada masa kanak-kanak.

Tanggung jawab menurut Suyadi (2013) memiliki definisi sikap dan perilaku seseorang dalam melaksanakan tugas dan kewajiban baik yang berkaitan dengan diri sendiri, sosial, masyarakat, bangsa dan negara maupun agama. Sedangkan Lickona (2012) berpandangan bahwa tanggung jawab menekankan pada hal-hal yang hari ini dianggap penting sebagai perbaikan di masa yang akan datang. Dengan demikian, tanggung jawab mahasiswa adalah sikap dan perilaku mahasiswa sesuai dengan tugas dan kewajibannya.

Fenomena yang terjadi di kalangan mahasiswa masih banyak yang belum memiliki karakter tanggung jawab baik sikap maupun perilakunya misalnya dalam melaksanakan tugas dan kewajibannya. Hasil observasi dan interviu terhadap mahasiswa dan dosen diperoleh data tentang sikap perilaku mahasiswa yang kurang bertanggung jawab secara akademis terkait dengan sikap di antaranya mengerjakan tugas dengan terpaksa, bersikap pasif atau malas berpikiran maju, motivasi kurang, cenderung cuek, kurang cakap dalam berkomunikasi terhadap sesama teman maupun dosen baik secara langsung masupun lewat teknologi seperti mengirim sms, watsapp, blackberry messanger, email dan lain-lain. Selain itu perilaku kurang bertanggungjawab seperti menunjukkan perilaku yang tidak pantas, misalnya penampilan pada saat presentasi masih belum menggambarkan seorang mahasiswa karena hanya membaca dengan bahan yang seadanya, ngobrol pada saat kuliah, mengerjakan tugas tidak maksimal, kurang berpartisipasi dalam diskusi kelompok, kurang berpartisipasi selama proses pembelajaran, kurang disiplin dengan terlambat masuk kuliah, mencoret-coret meja kuliah, tugas dikerjakan kurang maksimal selain penampilan fisik kurang menggambarkan seorang mahasiswa. Gejala-gejala tersebut mengindikasikan lemahnya karakter tanggung jawab sebagai mahasiswa.

Berdasarkan fenomena di atas, maka perlu adanya metode untuk mengembangkan karakter tanggung jawab pada mahasiswa. Pendidikan karakter memiliki sejumlah pendekatan dan metode dalam membentuk karakter di antaranya dari dimensi kognitif terdapat tiga pendekatan yang dapat diambil yaitu pendekatan perkembangan moral kogitif, pendekatan analisis nilai, dan pendekatan klarifikasi nilai. Ketiga pendekatan kognitif tersebut dapat diaplikasikan dalam pengajaran denggan menggunakan meode diskusi yang bervariasi dan komunikatif anatara dosen dan mahasiswa, salah satunya dapat dilakukan dengan diskusi menggunakan kasus dilema moral. Dimensi afektif dilakukan dengan pendekatan penanaman nilai menggunakan metode pembelajaran reflektif, story telling dan 
biblioterapi. Dimensi yang ketiga yaitu dimensi psikomotorik menggunakan pendekatan pembelajaran berbuat dengan metode sosiodrama dan role play (Elmubarok, 2006). Dalam penelitian ini akan menguji metode biblioterapi Islam untuk meningkatkan karakter tanggung jawab pada mahasiswa.

\section{Landasan Teori}

\section{Biblioterapi}

Metode biblioterapi digunakan karena metode ini menggunakan informasi atau pengetahuan yang terdapat dalam buku pustaka sebagai upaya dalam membantu individu dalam memenuhi kebutuhan dan mengoptimalkan potensinya. Dijelaskan oleh Pehrsson \& McMillen (2006) bahwa bibliotherapy adalah membaca dan mendiskusikan buku-buku tentang situasi yang mirip dengan apa yang dialami oleh mahasiswa. Melakukan kegiatan membaca dan berdiskusi buku benar-benar dapat membantu siswa dalam beberapa cara. Beberapa mahasiswa memiliki kesulitan dalam verbalisasi pikiran dan perasaan mereka dan bibliotherapy memberikan kesempatan bagi mahasiswa untuk menghubungkan masalah mereka sendiri dengan situasi dalam sebuah buku.

Menurut Roselina dan Shukry (2006) menjelaskan bahwa metode biblioterapi dapat digunakan untuk membentuk konsep diri positif, memahami tingkah laku dan motivasi remaja, melegakan tekanan emosi, serta mendiskusikan masalah penyimpangan moral secara terbuka untuk melihat berbagai pilihan dalam penyelesaian masalah. Pernyataan tersebut diperkuat oleh Hidayat (2008) yang mengemukakan bahwa metode biblioterapi dapat digunakan untuk mengatasi masalah kebingungan remaja terhadap nilai-nilai moral yang bila tidak segera ditangani dapat menyebabkan terjadinya kenakalan remaja.

Berdasarkan beberapa pendapat tersebut di atas, dapat dinyatakan bahwa biblioterapi adalah salah satu metode yang digunakan untuk mengintervensi moral individu dalam menanamkan nilai-nilai moral positif yang salah satunya tanggung jawab.

\section{Tanggung Jawab}

Tanggung jawab secara literal berarti "kemampuan untuk merespon atau menjawab". Artinya, tanggung jawab berorientasi terhadap orang lain, memberikan bentuk perhatian dan secara aktif memberikan respon terhadap apa yang diinginkan. Sehingga tanggung jawab menekankan kewajiban positif untuk saling melindungi satu sama lain (Lickona, 2012). Selanjutnya Lickona (2012) menyebutkan bahwa tanggung jawab berarti melaksanakan sebuah pekerjaan atau kewajiban dalam keluarga, di sekolah, maupun di tempat bekrja dengan sepenuh hati dan memberikan yang terbaik. 
Orang yang bertanggung jawab menurut Samani dan Hariyanto (2012) memiliki ciri yaitu melakukan tugas dengan sepenuh hati, bekerja dengan etos kerja yang tinggi, berusaha keras untuk mencapai prestasi terbaik (giving the best), mampu mengontrol diri dan mengatasi stres, berdisiplin diri, bertanggungjawab terhadap pilihan dan keputusan yang diambil. Karakter tanggung jawab menurut Clarken (2010) harus memenuhi tiga hal yaitu mampu mengendalikan diri, yang artinya memiliki tanggung jawab sebagai pribadi untuk menjalankan tugas semaksimal mungkin; mengakui kesalahan dan kegagalan, yaitu memiliki keberanian menanggung resiko atas kegagalan atau kesalahan dalam mengambil keputusan ; dan memiliki kesungguhan dalam melayani orang lain. Demikian halnya dengan yang dikemukakan oleh Zuriah (2007) bahwa karakter tanggung jawab yaitu mengembangkan keseimbangan antara hak dan kewajiban, berani menghadapi konsekuensi dari pilihan hidup dan mengembangkan sikap hidup bermasyarakat yang positif.

Berdasarkan penjelasan teoritis di atas, maka hipotesis dalam penelitian ini adalah terdapat pengaruh metode biblioterapi Islam dalam mengembangkan karakter tanggung jawab pada mahasiswa.

\section{Metode Penelitian}

Penelitian ini menggunakan eksperimen kuasi (quasi experimental design) dengan desain dua kelompok. Jenis desain yang digunakan dalam penelitian nonequivalent control group design. Desain penelitian ini merupakan sebuah desain penelitian yang membandingkan satu kelompok eksperimen dengan kelompok pembanding yang nonequivalent, diawali dengan pretest yang diberikan kepada kedua kelompok, kemudian diberi perlakuan (treatment) pada kelompok eksperimen. Penelitian diakhiri dengan posttest yang diberikan kepada kedua kelompok (Sugiyono, 2013). Adapun gambaran mengenai rancangan nonequivalent control group design (Sugiyono, 2013) sebagai berikut,

Tabel 1. Desain Penelitian Eksperimen Nonequivalent Control Group Design

\begin{tabular}{cccc}
\hline Kelompok & Pretest & Perlakuan & Postest \\
\hline $\mathrm{KE}$ & $\mathrm{O}_{1}$ & $\mathrm{X}$ & $\mathrm{O}_{2}$ \\
$\mathrm{KK}$ & $\mathrm{O}_{3}$ & & $\mathrm{O}_{4}$ \\
\hline
\end{tabular}

\section{Keterangan:}

KE: Kelompok Eksperimen

KK: Kelompok Kontrol

$\mathrm{O}_{1}$ : Pretest yang dilakukan pada kelompok eksperimen sebelum perlakuan 


\section{WACANA}

$\mathrm{O}_{2}$ : Posttest yang dilakukan pada kelompok eksperiman sesudah perlakuan

X: Pemberian Perlakuan

$\mathrm{O}_{3}$ : Pretest yang dilakukan pada kelompok kontrol sebelum perlakuan

$\mathrm{O}_{4}$ : $\quad$ Posttest yang dilakukan pada kelompok kontrol sesudah perlakuan

Sampel dalam penelitian ini berjumlah 11 orang mahasiswa Fakultas Psikologi UIN Suska Riau yang terdiri dari satu kelas kelompok eksperimen berjumlah 6 orang dan satu kelas kelompok kontrol berjumlah 5 orang, dengan kriteria: (1) beragama islam, (2) memiliki skor skala karakter tanggung jawab pada kategori rendah.

Metode pengumpulan data yang digunakan dalam penelitian ini adalah skala karakter tanggung jawab yang meliputi aspek (1) mampu mengendalikan diri, (2) berani mengambil resiko atas pilihan, (3) memiliki kesungguhaan dalam menjalankan kewajiban terhadap orang lain. Penyusunan skala diawali dengan uji validitas dengan expert judgment. Pemilihan aitem valid dilakukan dengan teknik corrected item total correlation. Sedangkan reliabilitas kala dengan menggunakan alpha cronbach.

Pada pelaksanaan eksperimen, subjek dibagi menjadi dua kelompok yaitu 6 orang sebagai kelompok eksperimen dan 5 orang sebagai kelompok kontrol. Masing-masing kelompok dilakukan pre test dan post test. Pada kelompok eksperimen diberikan perlakuan. Perlakuan pada kelompok eksperimen dilakukan selama tiga sesi. Pada setiap sesinya membaca dan membahas kisah Nabi Yusuf AS. Pada akhir sesi, subjek diminta untuk mengambil pesan moral dari kisah Nabi Yusuf AS.

Setelah data pre dan post test dari kelompok eksperimen dan kelompok kontrol terkumpul melalui skala karakter tanggung jawab, maka dilanjutkan dengan analisis data dengan menggunakan gain skor pre test dan post test pada kelompok eksperimen dan kelompok kontrol.

\section{Hasil dan Pembahasan}

Uji hipotesis dilakukan dengan menggunakan gain skor pre test dan post test pada kelompok eksperimen dan kelompok kontrol. Hasil skor rerata kelompok eksperimen dan kelompok kontrol sebagai berikut : 
Tabel 2. Skor rerata karakter tanggung jawab Kelompok Eksperimen dan kelompok kontrol

\begin{tabular}{ccccc}
\hline Kelompok & Perlakuan & $\begin{array}{c}\text { Rerata } \\
\text { pre } \\
\text { test }\end{array}$ & $\begin{array}{c}\text { Rerata } \\
\text { post test }\end{array}$ & $\begin{array}{c}\text { Rerata gain } \\
\text { skor }\end{array}$ \\
\hline eksperimen & 6 & 61.31 & 68.45 & -7.14 \\
kontrol & 5 & 60.56 & 61.14 & -0.58 \\
& & & & \\
\hline
\end{tabular}

Berdasarkan tabel di atas memberikan gambaran bahwa terjadi peningkatan skor paling banyak pada kelompok eksperimen yaitu kelompok yang diberi perlakuan biblioterapi, ditunjukkan rerata gain skor -7.14. Hal ini berarti bahwa metode biblioterapi islam berpengaruh terhadap pengembangan karakter tanggung jawab pada mahasiswa.

Hasil penelitian ini didukung oleh pendapat Floyd et all (2004) yang menjelaskan bahwa modifikasi perilaku untuk mengintervensi perilaku seseorang dapat dilakukan dengan tiga cara yaitu biblioterapi, psikoterapi kognitif individu, dan treatment tertunda. Menurut Ready (2002) cerita dalam biblioterapi dapat memberikan dampak yang efektif karena biblioterapi memiliki isi cerita yang spesifik, tingkat atau kadar yang sesuai karakteristik subjek, diberikan oleh guru/role model yang dihormati siswa, cerita yang diberikan memiliki kesan drama (berkesan), serta memiliki kandungan nilai belajar yang tinggi sehingga mampu menjadi salah satu bentuk intervensi psikologis yang memiliki kekuatan mengubah.

Biblioterapi merupakan sebuah proses dinamis interaksi antara buku dengan pembaca, proses tersebut bermanfaat untuk assesmen, penyesuaian, dan pertumbuhan kepribadian. Penggunaan teknik ini dalam kelas dapat sebagai tindakan terapi maupun preventif ( Olsen, 1975). Menurut Maich dan Kean (2004) suatu intervensi psikologis dengan meode biblioterapi menjadi bernilai karena pesan moral yang terkandung cerita dapat berpengaruh secara positif di dalam pikiran tidak sadar individu bahkan meskipun pikiran tidak sadar tersebut sedang tidak aktif dalam proses informasi. Sehingga kesan yang dihasilkan akan terekam dalam waktu yang relatif lama.

Hasil penelitian juga didukung oleh penelitian Sweeney (2008) yang mengemukakan bahwa penggunaan cerita untuk mengajarkan karakter menunjukkan peningktan yang signifikan dalam pemahaman siswa tenrhadap konsep karakter baru apabila memenuhi syarat sebagai berikut: setelah diberikan suatu cerita bermuatan nilai karakter tertentu kemudian guru mengajak diskusi dan sharing secara efektif sehingga siswa mampu 
memahami dan mengambil hikmah dari cerita yang diberikan, sebelum cerita diberikan terlebih dahulu dibuat modul yang berfugsi sebagai alat untuk memperkuat ide-ide dari cerita yang diberikan, kemampuan guru memilih cerita yang benilai sebagai pendekatan dan pengajaran, dan kemampuan guru memilih cerita yang dapat masuk ke semua kalangan jika siswanya berasal dari latar belakang yang heterogen.

Penggunaan biblioterapi memiliki nurturent effects yakni mendekatkan mahasiswa pada buku simana era digital ini mahasiswa cenderung lebih dekat pada gadget dibanding dengan membaca buku dalam bentuk cetak. Menurut Mangen, Walgermo, dan Bronnick (2013) siswa yang lebih sering membaca pada layar digital memiliki kemampuan memahami bacaan yang lebih rendah dibanding siswa yang lebih sering membaca buku teks dalam bentuk cetak, sehingga temuan ini memiliki implikasi pedagogis yang harus dipertimbangkan untuk memaksimalkan kinerja otak pada siswa.

Metode biblioterapi pada kisah Nabi Yusuf AS sangat tepat untuk digunakan sebagai media konseling rasional emotif dalam mereduksi pemikiran irrasional seseorang menjadi pemikiran rasional. Karena pada dasarnya manusia adalah unik yang memiliki kecenderungan untuk berpikir rasional dan irrasional. Mahasiswa yang bertindak irrasional dengan tidak bertanggung jawab terhadap kehidupannya sendiri menjadi bertanggungjawab dengan diberikan perlakuan membaca kisah nabi Yusuf AS. Dengan membaca kisah Nabi Yusuf AS, mahasiswa ditantang untuk dapat bertanggung jawab. Misalnya mahasiswa mengatakan: "Saya akan menjadi Bunyamin", yang memberikan bantuan menanggapi: "dapatkah anda dipercaya untuk menjaganya padahal dahulunya anda tidak bisa menjaga adikmu yang lain."

\section{Kesimpulan}

Karakter tanggung jawab diperlukan bagi mahasiswa sebagai generasi penerus bangsa yang bermartabat. Karakter tanggung jawab tidak dibawa sejak lahir tetapi dibangun melalui proses pendidikan karakter. Karakter tanggung jawab mahasiswa dapat dikembangkan melalui biblioterapi Islam. Biblioterapi Islam mengembangkan karakter tanggung jawab mahasiswa seperti (1) mampu mengendalikan diri, (2) berani mengambil resiko atas pilihan, (3) memiliki kesungguhaan dalam menjalankan kewajiban terhadap orang lain. 


\section{Daftar Pustaka}

Clarken, R. (2010). Considering Moral Intelligence. As Part of A Holistic Education. Denver: Northern Michigan University.

Creswell, J. W. (2010). Research Design. Pendekatan Kualitatif, Kuantitatif, dan Mixed. Yogyakarta: Pustaka Pelajar.

Elmubarok, Z. (2008). Membumikan Pendidikan Nilai mengumpulkan yang Terserak, Menyambung yang Terputus, dan Menyatukan yang Tercerai. Bandung: Alfabeta.

Floyd, M., Scogin, F., Smith, N., Floyd, D., \& Rokke, P. (2004). Cognitive Therapy for Depression: A Comparison of Individual Psychotherapy and bibliotherapy for Depressed Older Adults, Journal of Behavior Modification, 28 (2), 297-318.

Furqon, Hidayatullah. (2010). Pendidikan karakter: Membangun Peradaban Bangsa. Surakarta: Yuma Pustaka.

Hidayat, M.Y. (2008). Alikasi Biblio-konseling Sebagai Salah Satu Strategi Membantu Klien dalam Konseling. Jurnal Lentera Pendidikan, 11 (1), 129-140.

Hurlock, E. (2000). Psikologi Perkembangan: Sepanjang Rentang Kehidupan. Terjemahan (Edisi Kelima). Jakarta: Erlangga.

Lickona, Thomas. (2012). Educating for Character, How Our Schoolcan Teach Respect and responsibility. (Terjemahan). Jakarta: Bumi Aksara.

Maich, K., \& Kean, S. (2004). Read Two Books and Write In The Morning! Bibliotherapy in for Social Emotional Intervention in The Inclusive Class-room. Teaching Exceptional Children, 1(2), 5-11.

Mangen, A., Walgermo, B., Bronnick. (2013). Reading Linear Texts on papper Versus Computer Screen: Effects of Reading Comprehension. International Journal of Educational Research. 5(58), 61-68. Doi:10/1016/j.ijer.2012.12.002.

Muchlas, S \& Hariyanto, M.S. (2012). Pendidikan karakter. Bandung: remaja Rosda karya.

Sugiyono. (2013). Metode Penelitian Manajemen. Bandung: Alfabeta

Suyadi. (2013). Strategi Pembelajaran Pendidikan karakter. Bandung: Remaja Rosda Karya.

Olsen, H. (1975). Bibliotherapy to Help Children Solve Problems. The Elementary School Journal. 75(7), 422-429.

Pehrsson, Dale-Elizabeth and McMillen, Paula. (2006). Competent Bibliotherapy: Preparing Counselors to Use Literature with Culurally Diverse Clients. ACA: Vistas Online.

Ready, D.A. (2002). How Story Telling Builds Next Generation Leaders. Massachusetts: EBSCHO Publishing.

Roselina \& Shukry, M. (2006). Bibliotherapy: A Tool for Primary Prevention Program With Children and Adolescents. Jurnal Antidadah Malaysia, 1(1), 75-90

Sweeney, L. (2008). The Case For Character Education. Sydney: Marsh Media White Paper.

Zuriah, N. (2007). Pendidikan Moral dan Budi Pekerti dalam Perspektif Perubahan. Jakarta: Bumi Aksara. 
WACANA 